\title{
Urodimento
}

REVISTA DE ESTUDOS EM ARTES CÊNICAS

E-ISSN 2358.6958

\section{O teatro cômico e musicado na Primeira República: A presença da cultura afro-brasileira na cidade do Rio de Janeiro}

\author{
Luciano Corrêa Loureiro
}

\section{Para citar este artigo:}

LOUREIRO, Luciano Corrêa. O teatro cômico e musicado na Primeira República: A presença da cultura afro-brasileira na cidade do Rio de Janeiro. Urdimento - Revista de Estudos em Artes Cênicas, Florianópolis, v. 2, n. 41, set. 2021.

do) DOI: http:/dx.doi.org/10.5965/1414573102412021e0106

Este artigo passou pelo Plagiarism Detection Software| iThenticate 


\title{
Resumo
}

Este artigo tem por finalidade trazer à tona algumas problematizações acerca da presença do teatro cômico e musicado durante a Primeira República, suas perspectivas históricas e memórias, mas, sobretudo, todo um conjunto de embates e depreciações promovidos por elites do período exatamente por esse teatro ser uma representação artística popular de sucesso, contrária aos interesses intelectuais da época e manifestadamente representante da cultura afro-brasileira em solo carioca.

Palavras-chave: Teatro cômico e musicado. Rio de Janeiro. Praça Tiradentes. Resistência.

\section{The comic and musical theater in the First Republic: \\ The presence of Afro-Brazilian culture in the city of Rio de Janeiro}

\begin{abstract}
This article aims to bring up some problematizations about the presence of comic and musical theater during the First Republic, its historical perspectives and memories, but, above all, a whole set of clashes and depreciations promoted by elites of the period exactly because this theater is a popular artistic representation, of success, contrary to the intellectual interests of the time and manifestly representative of Afro-Brazilian culture in Rio soil.
\end{abstract}

Keywords: Comic and musical theater. Rio de Janeiro. Tiradentes Square. Resistance.

\section{El teatro cómico y musical en la Primera República: \\ La presencia de la cultura afrobrasileña en la ciudad de Río de Janeiro}

\section{Resumen}

Este artículo pretende traer a colación algunas problematizaciones sobre la presencia del teatro cómico y musical durante la Primera República, sus perspectivas históricas y recuerdos, pero, sobre todo, todo un conjunto de enfrentamientos y depreciaciones promovidas por las élites de la época precisamente porque este teatro es una representación artística popular, de éxito, contraria a los intereses intelectuales de la época y manifiestamente representativa de la cultura afrobrasileña en suelo rionera.

Palabras clave: Teatro cómico y musical. Rio de Janeiro. Plaza Tiradentes. Resistencia.

${ }^{1}$ Mestrado em História pela Universidade Federal do Estado do Rio de Janeiro (UNIRIO). Especialista, LatoSensu, em Educação pela Universidade Estadual do Estado do Rio de Janeiro (UERJ). Licenciado em Educação Artística, com habilitação em artes cênicas e Bacharelado em Artes Cênicas, com habilitação em interpretação teatral, ambos UNIRIO. Professor de cargo efetivo em Artes Cênicas no Curso Técnico de Artes Dramáticas, da Escola Técnica Estadual de Teatro Martins Penna (ETETMP-RJ). Lucianocloureiro@gmail.com (9) http://lattes.cnpq.br/1146128999128586 
Dedico esse artigo a Erika Ferreira Elias (in memoriam), ex-aluna dedicada, mulher, negra e artista potente.

A existência e popularidade do teatro cômico e musicado² ao longo da Primeira República no centro da cidade do Rio de Janeiro, mais precisamente na Praça Tiradentes e seu entorno, ainda é um fenômeno artístico-histórico-cultural pouco estudado, repleto de lacunas a serem preenchidas e que, portanto, oferece considerável e substancial material a ser levantado para a realização de inúmeras e merecidas pesquisas históricas, e em espectros dos mais variados, quando tratamos de uma época tão rica para a História das Artes Cênicas.

Neste artigo tentaremos emergir com algumas questões e problematizar, ainda que sinteticamente, sobre os efeitos socioculturais e políticos da presença de elementos performáticos afro-brasileiros existentes no teatro cômico e musicado e de algumas das suas tradições reapropriadas e levadas para o palco. O aspecto estético contido na própria natureza e essência do teatro cômico e musicado vinha causando, desde meados do século XIX, embates e conflitos ideológicos que incomodavam consideravelmente boa parte da intelectualidade brasileira. Ainda, como poderemos ver mais adiante, havia todo um esforço não apenas dessa classe intelectual, mas também daqueles que detinham o poder do capital, de promover o apagamento do teatro cômico e musicado. A questão aqui era afastar características culturais afro-brasileiras dos palcos e das ruas da Capital de uma recém-instalada República, que ambicionava se aproximar cada vez mais de valores europeus brancos e, conforme suas crenças, civilizados. Para isso era urgente impor todo um projeto de desprestigio que pudesse reverter simbolicamente em novos valores étnicos, didáticos e estéticos opostos ao que o teatro cômico e musicado oferecia e, consequentemente, através da dominação cultural, alcançar a dominação econômica. Em outras palavras, havia um projeto

${ }^{2}$ As revistas, vaudevilles, burletas, bulevar, mágicas e operetas, serão citadas, genericamente, nesse artigo na modalidade de teatro cômico e musicado. Embora cada um desses gêneros possuísse suas características próprias, todos localizavam-se no âmbito da cultura "popular" e tinham como princípio o divertimento. Seus textos, personagens-tipo e músicas, possuíam uma irreverência crítica aos costumes, usos e modos da sociedade a partir da construção de cenas ou quadros cômicos e/ou musicais. 
de Estado político, cultural e econômico para a cidade do Rio de Janeiro no qual não caberia a exposição de tradições e demonstrações da cultura afro-brasileira, considerada primitiva e nociva, pertencentes a ex-escravizados e seus descendentes.

\section{O Teatro Cômico e Musicado: um obstáculo aos interesses culturais e econômicos das elites}

O "caráter-nacional" definido por um Brasil republicano e eugênico², com seu projeto modernista, figuraria um mundo de imprecisões e ambivalências. Assim, a crise entre elites intelectuais e fazeres artísticos de caráter popular ${ }^{4}$ e de significativa abrangência para uma população trabalhadora, negra e mestiça se revelaria importante para o entendimento de confrontos estéticos-identitários no período. Confrontos que não apenas circulariam na vida de cariocas e fluminenses, mas por todo um segmento nacional de fisionomia eurodescendente e conservadora.

Como já salientamos, não podemos nos furtar aqui em registrar nossa hipótese que a recorrente depreciação promovida pelas elites intelectuais contra o teatro cômico e musicado irrompe, indisfarçadamente, patrocinado por setores burgueses da sociedade, com notórios interesses econômicos, apropriação e dominação cultural. Tal conduta das elites intelectuais e da burguesia se alinhava ao propósito, desde muito explicitado, de instaurar definitivamente aquilo que se defendia e denominava como "teatro sério". Valeria concretizar velhos anseios para a cidade do Rio de Janeiro, com todo um conjunto de mobilizações no sentido de se obter o controle daquilo que seria ou valeria como "moderno" e rentável. O Centro do Rio de Janeiro, principalmente após as reformas implementadas por

\footnotetext{
${ }^{3}$ A eugenia no Brasil seria bem-vinda como uma forma de "saneamento e/ou branqueamento da raça", visto que durante o período havia a crença infundada de que as várias epidemias que assolavam o Rio de Janeiro seriam culpa e responsabilidade de toda uma população negra, recém-liberta com a abolição da escravatura e disseminada pela cidade. Mais sobre práticas eugênicas durante a Primeira República, ver: Schwarcz, 1993.

“ Distinções metodológicas sobre o que seria cultura "popular" e "erudita", com evidente valorização e importância da segunda, acreditamos, estão envoltos em toda uma narrativa de vontades das elites como fator decisivo à divisão de classes e, por conseguinte, na manutenção das diferenças sociais. Para maiores detalhes, ver: Chartier, 1995, p.179-192.
} 
Pereira Passos entre 1902 e 1906, ganhava cada vez mais o status de Centro Financeiro e Econômico da cidade com seus "arranha céus" construídos na novíssima Avenida Central, ${ }^{5}$ destinados ao mundo dos negócios. De fato, havia um projeto de cidade que ambicionava se remodelar (reinventar) a partir dos padrões europeus, especialmente franceses. "[...] A ilusão do intelectual burguês era a de que, à sua imagem e semelhança, o tipo-síntese do carioca-brasileiro poderia adotar o perfil de um europeu tropical [...]” (Lopes, 2000, p.22).

\section{O Teatro Cômico e Musicado e as dissenções socioculturais com as elites intelectuais e burguesas}

Outro aspecto importante para se entender a relevância e embates ocasionados pela existência do teatro cômico e musicado na cidade do Rio de Janeiro, durante a Primeira República, está intrinsicamente ligado a um lugar de memória e identidade. Fenômeno de entretenimento e socialização para a população, no qual a própria representação da cidade em seus palcos surge como um agente interativo da construção de um imaginário urbano e, em certa medida, idealizado da vida cultural, o sucesso do teatro cômico e musicado gerava embates artísticos-intelectuais exatamente por ser partícipe na construção de uma identidade cultural da então Capital Federal e oposta aos interesses burgueses e "liberais" vigentes.

Uma possível e plausível explicação para o êxito frente ao público ao longo desse período parece estar não apenas na utilização de recursos cênicos disponíveis então - eminentemente imagéticos, grandiosos, com técnicas que acentuavam todo um conjunto "plástico", moderno, futurista para as coreografias, os cenários e figurinos - mas em especial pela empatia frente ao público, seja pela contemporaneidade dos temas tratados, a fácil apreensão dos enredos, a apresentação de tipos brasileiros faceiros, com seus modos e costumes, as melodias e ritmos com nossas cores, o corpo "carnavalizado", representando sempre com muita graça mas, sobretudo, com um modo de fazer teatral onde, 
sem se abster da crítica social, mas com muita imaginação, os desejos e mazelas de um povo por demais sofrido estavam sempre presentes na cena. Ou como bem coloca Verena Alberti (1999, p.12):

O estatuto do riso como redentor do pensamento não poderia ser mais evidente. O riso e o cômico são literalmente indispensáveis para o conhecimento do mundo e para a apreensão da realidade plena.

Dando a devida atenção aos processos históricos do período, não poderíamos deixar de mencionar, e de tentar entender, os alinhamentos contrários de grupos distintos que, em muitos casos, foram constituídos sobre certas indisposições de cunho racial, cultural, social, econômico e político. Em termos, de um lado, defensores do teatro de texto e da arte erudita, do outro, aqueles que realizavam práticas culturais e artísticas populares e que pertenciam a determinados segmentos sociais que não encontravam nenhuma manifestação de interesse ou apoio por parte do governo instituído. Tratamos aqui daqueles exclusos dos grandes planos de Estado arquitetado pelas elites e em conformidade com possíveis projetos civilizatórios que a cidade almejava.

Assim, a questão aqui se divide - e problematiza-se - em dois aspectos maiores. O primeiro evidencia no que os grupos econômicos majoritários e/ou intelectuais do período se interessavam em investir e quais bens culturais deveriam ser criados, evidenciados ou remodelados. O segundo, em contraposição aos interesses destes mesmos grupos elitistas, buscava encontrar espaços e direcionamentos que fossem capazes de distinguir práticas artístico-populares concretizadas por grupos culturais moradores da periferia da cidade do Rio de Janeiro, em especial, os residentes da "Pequena África", ${ }^{6}$ e de que maneira emprestaram para os palcos dos teatros da Praça Tiradentes, e seu entorno, todo um conjunto de experiências complexas e sofisticadas de matriz negra. Cabe ressaltar que, de modo estrito, esse modelo de teatro não se apartou de vínculos com uma estrutura europeia, mantendo-se quase sem qualquer alteração daquilo

6 "Pequena África”, nome cunhado pelo artista Heitor dos Prazeres, espaço reconhecidamente como território de influência africana, é como ficou conhecida a área hoje composta na cidade do Rio de Janeiro pelos bairros da Saúde, Gamboa, Santo Cristo e Morro da Providência, desde a Praça Mauá até a Cidade Nova, na virada do século XX. 
que já, desde muito, era apresentado pelas companhias estrangeiras que aqui se apresentavam anualmente. Assim, mesmo compreendendo a não ruptura com certas acepções do mundo literário e das correntes culturais europeias defendidas pelas elites, não podemos deixar de destacar que essa estrutura, em mesma proporção, sofre significativas distinções simbólicas exatamente pela inserção de elementos da cultura afro-brasileira, seja nos corpos que dançam e atuam, nos textos ou nas partituras musicais. ${ }^{?}$

Como síntese, precisamos elencar e reconhecer presentemente todo um conjunto plural de pontos de vista culturais, conflitantes e dialéticos que se incorporaram ao debate sobre as definições de: cidade, progresso, identidade e modernidade.

\section{História Cultural e Memória: perspectivas culturais e altercações em uma República recém-inaugurada}

Para elencar tais questões, em muitos casos difusas ou até mesmo contraditórias, optamos em compor com a História Cultural e a Memória um campo investigativo e metodológico por suas implicações e afinidades a teses propostas nos campos do estudo da Historiografia e Memória Social. Acreditamos, portanto, que o conceito de Memória e a História Cultural podem ser excelentes por seu caráter plural e suas premissas de orientação científica.

Com a disposição de textos e do pensamento e compreensão de certos autores significativos em questões ligadas a História e Memória, podemos alinhavar caminhos para este tema. Importantes apreciações sobre estudos relativos à memória encontram-se em diversos autores. Aqui mobilizaremos, em particular, algumas reflexões produzidas por Michael Pollak e Maurice Halbwachs.

Memória é o ingrediente inevitável ao historiador, poderíamos dizer de modo genérico, sendo ela uma edificação psíquica e cognitiva capaz de produzir representações seletivas do passado em um contexto social e cultural mais amplo. Em outros termos, a história de uma localidade, uma esquina, um quarteirão, uma

Talvez nenhum outro exemplo seja tão evidente como no caso do futebol. Inicialmente, um esporte importado da Europa, mas que ganha nova fisionomia e volume quando apropriado aos gingados de um corpo afro-brasileiro. 
rua, de um indivíduo, uma ocasião ou um elemento arquitetônico que pode ter seu valor alterado frente ao conhecimento e/ou observação e interesses no presente ou para o futuro.

Neste aspecto, Halbwachs é especialmente útil para esse trabalho, trazendo distinções significativas entre aquilo que poderíamos entender por memórias individuais e coletivas, sendo a primeira como "um ponto de vista sobre a memória coletiva" e, por conseguinte, produzindo alterações e se colocando, portanto, num sucessivo processo de percepções e reelaborações de acordo com as perspectivas do meio. Ainda segundo o autor, a memória se apresenta como uma reconstrução do passado a partir de informações recolhidas do presente, que, por desdobramento, é nutrida e reestruturada por outros momentos decorridos. Assim, para Halbwachs (1990), a memória entre grupos pode ser construída ou simulada.

A teoria exposta pelo autor é bastante sugestiva e se adequa sobremaneira aos procedimentos culturais que desenham todo o caminho e realizações do teatro cômico e musicado e suas inseparáveis relações com as culturas europeia e afro-brasileira. Inserido em uma República recém-inaugurada, com suas múltiplas narrativas, embates, altercações e aspirações culturais diversas, não seria errado especular por sobre variações realizadas com o objetivo em se adequar ou graduar certas tradições da cultura afro-brasileira às necessidades estéticas e linguísticas intrínsecas à cena teatral urbana do período. Uma memória presente e modelável aos imperativos que o momento demandava, conferindo novos e amplos sentidos e usos das tradições. Fato que ocorria concomitantemente, e em interação, com a música, com os maxixes e sambas.

Para Michael Pollak (1992), a memória coletiva tem por responsabilidade conservar a coesão de identidades grupais, assim como resguardar suas tradições com um "sentimento de pertencimento". Esse argumento é importante para reconhecer a presença do teatro cômico e musicado como a principal manifestação artístico-cultural durante a Primeira República na cidade do Rio de Janeiro, assim como toda a esfera simbólica de socialização que se perfez na Praça Tiradentes, fato capaz de dimensionar sua real importância. Cabe ainda entender e observar a extensão e repercussão do teatro cômico e musicado e sua 
perseverança para uma disputa "implícita” (talvez até inconsciente), motivada por sua recorrente e insistente popularidade, em prol da preservação de bens culturais plenamente identificáveis para com a população negra e mestiça vivente da cidade.

\section{História Cultural e novas e possíveis abordagens da historiografia do teatro brasileiro}

Abordando agora nomeadamente as contribuições da História Cultural e os pressupostos teóricos que ela pode oferecer para esse trabalho, utilizaremos as reflexões do historiador Roger Chartier para pensar sobre a presença do teatro cômico e musicado na Praça Tiradentes e seu entorno. Posto como um evento cultural e popularíssimo, de produção quase industrial e na alvorada daquilo que

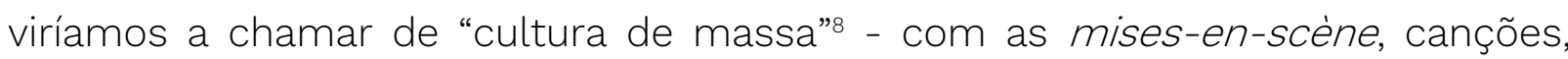
quadros e apoteoses de grande sucesso e um público cúmplice, sempre presente e prestigioso, nos coube o interesse pela observância de alguns conceitos históricos caros ao estudo da "cultura popular". Ou melhor, os debates que cercavam estas questões, tais como: identidade nacional, progresso, tradição, "raça" e etnia.

Entre os estudos que vêm sendo produzidos, nas últimas décadas, sobre o teatro cômico e musicado no período compreendido por este artigo, há semelhanças conceituais por parte de historiadores sobre a construção de um imaginário existente nos palcos, produto do reflexo do dia a dia da vida das pessoas na Primeira República. ${ }^{9}$ Ocorrência substancialmente responsável em exprimir, através da experiência histórica, o sentimento de pertencimento do sujeito a uma comunidade. Fica aqui a pertinência na utilização da História Cultural e sua viabilidade na produção de reflexões e problematizações capazes de sopesar a presença simbólica do teatro cômico e musicado inserido na vida mundana e urbana da cidade e suas práticas artísticas distintamente populares. Vale, portanto,

\footnotetext{
${ }^{8}$ Ver Umberto Eco. Apocalípticos e integrados. São Paulo: Perspectiva, 1993, 5a ed.

${ }^{9}$ Ver Tiago Gomes de Melo. Um espelho no palco: identidades sociais e massificação da cultura no teatro de
} revista dos anos 20. Campinas, São Paulo: Editora da Unicamp, 2004. 
o teatro cômico e musicado como representante de uma expressão e de uma linguagem produtora de significados no meio social.

Em meio a relações complexas, com diversos matizes conflitantes e em disputas permanentes entre - conceitos hoje bastante controversos - cultura popular versus cultura erudita, o fato é que a força da comicidade ganhava cada vez mais espaço, contrariando os anseios de uma elite intelectual que se mostrava mais interessada em afiançar outros valores, para ela, de maior relevância moral e intelectual e que exibia hostilidade ao teatro cômico e musicado, não apenas pela comicidade e divertimento, nos parece, mas também pela crítica bemhumorada dos vícios citadinos, ainda mais quando esse riso provinha de raízes pertencentes à cultura afro-brasileira. Afinal, o riso era o melhor que o teatro poderia oferecer para uma cidade emoldurada por desigualdades sociais, mas, contraditoriamente, também repleta de anseios em se tornar uma Paris dos trópicos.

Em meio a esse turbilhão de fatos, acontecimentos, juízos de valor, disputa de memórias, desejos e urbanismo que envolviam a cidade, precisamos, como bem assinala Chartier, tomar por objetos as representações do mundo social e fornecer a perspectiva necessária para uma abordagem crítico-apreciativa dessas próprias representações de mundo social. Representações alçadas e acentuadas pelas pretensões daqueles que conservam o poder econômico (capital) e, por desdobramento, o simbólico. Assim, segue o historiador, afirmando que as percepções que conseguimos extrair do social não são, de modo algum, discursos desinteressados ou imparciais:

As lutas de representações têm tanta importância como as lutas econômicas para compreender os mecanismos pelos quais um grupo impõe, ou tenta impor, a sua concepção de mundo social, seus valores e seus domínios. Como conclusão, nesse sentido, concepções de mundo social estariam, por diferentes modos e maneiras, e em diferentes situações, atreladas intrinsecamente a estruturas do poder (Chartier, 1990, p.17).

Cabe também, nesse processo de revisão por meio da História Cultural, superar envelhecidas e gastas formas de se constituir abordagens e estudos 
históricos teatrais por viés tradicionalista, sectário e, em muitos casos, substancialmente tendencioso que, inclusive, acabaram por levar a história do teatro no Brasil, escrita até os anos finais da década de 70 do século passado, a parcialidades emblemáticas de grupos ideologicamente identificáveis e com interesse próprio.

Assim, utilizar-se da História Cultural como base para uma nova escrita da historiografia do teatro brasileiro, onde dessa vez se dê voz aos "vencidos", mostrase um adequado caminho para se derrubar certo sistema de ideias postulado como "verdade". Chartier (1990) nos faz lembrar que o princípio da História Cultural é identificar o modo como, em múltiplos tempos e espaços, uma determinada realidade social é arquitetada e edificada e por quais meios essa ação se processa. Conclui o autor que para que tal análise ocorra tem-se que ter em vista as peculiaridades do ambiente e das práticas culturais ali elaboradas. Somente assim é possível compreender as complexidades distintas que concebem o lugar como representação. Para nós, portanto, o teatro que ocorria na Praça Tiradentes ao longo das últimas décadas do século XIX e iniciais do século XX, representam aqui fenômeno cultural e artístico manifestadamente popular, intricado, que se não se assumia diretamente como prática de resistência e de pertencimento da cultura de raiz negra, e ao mesmo tempo, de maneira dialética, persistia apesar de tantas e recorrentes ações de depreciação por parte de um grupo eurodescendente e conservador. O fato é que o teatro cômico e musicado era capaz de conter todo um conjunto de experiências transcorridas desde muito no teatro ocidental, e que revelaria todo um tecido social costurado por grupos relacionados à diversão, garantindo caracteres próprios à atividade teatral. Na cidade do Rio de Janeiro não seria diferente e assim, espaços de sociabilidade estariam abertamente relacionados às práticas cênicas e estéticas populares. Aliás, como bem salienta Denis Guènoun (2003), o teatro, além de ser atividade eminentemente política, tem como princípio não o representado, mas a representação. A constituição física, como assembleia ou reunião pública. Posto de outra maneira, e para o nosso caso em específico, espaços de sociabilidade ocorriam na Praça Tiradentes e em ruas no seu entorno onde, nos seus teatros, aconteciam trocas e extensões para ambos os lados entre o espectador e as cenas que ocorriam no palco, emergindo temas 
comuns e de interesse público. Por síntese, poderíamos dizer que, pelo exame da História Cultural, não poderíamos deixar de atribuir às expressões cênicas do período o resultado de todo um investimento comunitário e participativo de diversos atores sociais desejosos em exprimir coletivamente aquilo que pode ou deve ser transformável.

Precisamos considerar que o ato teatral historicamente não se resume a um momento transitório, efêmero, muito ao contrário, se materializa como substância indelével por apreender experiências vividas do passado, produzir considerações para o presente e proporcionar expectativas para o futuro. Sob o ponto de vista, mais uma vez, da História Cultural, poderíamos assertivamente dizer que a manifestação teatral é, sobretudo, produto flagrante de relações complexas que irão se concretizar plenamente apenas no espaço dedicado à representação e onde será empático e identificável a uma audiência.

\section{O teatro cômico e musicado, usos de memória, esquecimento e sua participação na construção da imagem do ser carioca}

São consideráveis as ações implementadas pelas elites do período, com o objetivo em conduzir certas práticas e narrativas que pudessem acolher e/ou favorecer seus intentos em prol da construção de um sentimento de nacionalidade. A ideia que parece prevalecer, como já postulamos, é, através da escolha e controle dos meios culturais - ou seja, determinando indiretamente aquilo que deveria ser representado - constituir um domínio ideológico e, consequentemente, ganhos políticos e econômicos. Porém, através de um olhar historiográfico, podemos perceber certas "sutilezas" em algumas atitudes que elevariam a questão e objetivo para embates entrelaçados à memória e pertencimento e, em absoluto subalternos, visto que, como afirma Le Goff (1984, p. 46): "[...] A memória é um elemento essencial do que se costuma chamar identidade, individual ou coletiva, cuja busca é uma das atividades fundamentais dos indivíduos e das sociedades de hoje [...]". Ou seja, ratificar o controle através de ações e iniciativas, pela proibição, depreciação, substituição ou até mesmo o silenciamento de certas práticas e heranças culturais afro-brasileiras presentes no 
teatro cômico e musicado.

Em observância a este aspecto da história do período, não podemos deixar de debater o propósito dessas elites com a tentativa de "construção" de uma "memória oficial", sobrepondo, obscurecendo, ou mesmo apagando, memórias de pertencimento de grupos de menor voz viventes na cidade, sendo a maioria desses, importante ressaltar, outrora cativos das senzalas ou seus descendentes.

Desde a Proclamação da República houve sistemáticas ações com o claro objetivo em se contrapor ao passado colonial e monárquico, substituindo, abolindo e/ou redefinindo símbolos, acontecimentos e personagens históricos para que se acomodassem mais confortavelmente aos novos tempos republicanos. Essa "memória oficial", que aos poucos vai reescrevendo a História do Brasil, tem por claro movimento seguir em direção a uma proposta de coesão social, nutrida a partir da edificação de um passado artificial, onde a presença e contribuição, ontem africana e hoje afrodescendente, seria sistematicamente apropriada por uma cultura de protagonismo branco e eurodescendente, ou seja, uma estratégia que, pelo pretérito histórico reescrito, se alçaria o pretexto para a construção dissimulada de uma ideia de forte adesão social harmoniosa, "cordial”, hegemônica e agora, exclusivamente brasileira e democrática. ${ }^{10}$

Dessa forma, o teatro cômico e musicado coexistia, nesse ambiente simbólico em que se apresentava a cidade do Rio de Janeiro, e não podemos nos furtar em assumir, reconhecidamente, a sua contribuição na descolonização do teatro brasileiro (Veneziano, 1991). Foi através do teatro cômico e musicado, em exemplo e comunhão com aqueles que ousavam frequentar e usufruir da Praça Tiradentes, que nossa cultura aflorou por sobre os palcos e para fora dele, alterando definitivamente os modos e costumes no dia a dia, evoluindo com a música, a dança e a alegria carnavalesca, encontrando e conhecendo as raízes e tradições afro-brasileiras, que até aqui, sofriam sistemáticas ações de silenciamento.

Estava nas origens de uma cultura urbana de massas que colocava em questão as percepções até então vigentes sobre a nossa identidade

10 Para maiores informações sobre esse tema, ler de Gilberto Freyre em: Casa Grande e Senzala, onde o autor sistematiza parâmetros do que seria intitulado de "democracia racial", teoria hoje bastante controversa, ao dissecar as relações cotidianas da família patriarcal colonial. 
cultural. Recusando uma forçada inserção numa cultura de elite ou popular, operando entre as tradições artísticas europeias e a presença insinuante das tradições africanas, acompanhando de perto as rápidas mudanças nos valores, [...] Esse potencial de um teatro entre o erudito e o popular estar formando uma "nova cultura" [...] (Lopes, 2000, p.14).

Desse embate entre múltiplas vontades, onde se situam história e memória, com efeito, resultaria, progressivamente, a identidade carioca. Também não podemos esquecer em citar toda a determinação dos nossos afrodescendentes, com o fim de um sistema escravocrata, para a criação de movimentos sociais empenhados em garantir às populações negra e mestiça direitos iguais perante a Lei e políticas de inserção social. ${ }^{11}$ Ou em outros termos, como bem salienta Pereira (2006, p.119):

As lutas da população negra no Brasil ganharam nova dimensão no período pós-abolição. Importantes organizações surgiram e se espalharam pelo país. Homens e mulheres negros, intelectuais, políticos, artistas, trabalhadores etc., se organizaram para lutar de diferentes formas contra a discriminação racial e por melhores condições de vida para a população negra.

Evidente, não nos cabe aqui, a propósito, constituir e/ou destacar qualquer tese particular em defesa, ou mesmo valorizar determinada narrativa sobre hegemonias ou ideologias, sejam elas brancas, mestiças ou negras. Até porque em se tratando de tema bastante complexo é preciso reconhecer um conjunto mais amplo em prol de demandas representativas de vivências na cidade do Rio de Janeiro. Presumimos aqui a impossibilidade para a elaboração de uma memória, que poderíamos dizer, tão-somente ou puramente individual, visto que lembranças individuais são, continuamente, resultado de composições de relação de pertencimento a um grupo. A memória individual ocorre como um elemento de interseção de múltiplos conjuntos, onde cada um possui suas próprias demandas sociais com interesses diversos e com capacidades próprias de articulação (Halbwachs, 1990).

A formação de identidades preza por processos híbridos, nos quais não se deve rejeitar as múltiplas participações dos vários agentes envolvidos, e com

${ }^{11}$ As primeiras manifestações de luta surgem com a imprensa negra paulista, cujo primeiro jornal, O Menelick, começa a circular em 1915. Posteriormente, A Rua (1916), O Alfinete (1918), A Liberdade (1919), A Sentinela (1920), O Getulino e o Clarim d'Alvorada (1924). 
interesses diversos. Somando-se ao debate, e no centro de questões sobre memória, é de igual relevância tratar o conceito de esquecimento como instrumento utilizado pelas elites (limitado ao tema e período estudado neste artigo), com a finalidade em fazer desaparecer um determinado passadopresente-histórico-teatral que não se coadunava a certos interesses estéticos afrancesados tão desejados à época.

Com o teatro cômico e musicado, elencado por grupos de intelectuais como produto pertencente a uma arte menor, "popularesca", de tal modo, distanciada de valores mais elevados e edificantes defendidos pela "História Magistra Vitae", ocorre o processo de inferência à ideia de inexistência ou irrelevância cultural e que, destarte deveria ser apagada de práticas artísticas da Capital Federal.

Esse expediente, primeiramente lançado por um segmento crítico e literário presente durante o século XIX e persistindo o incômodo durante a Primeira República, posteriormente, alcançou infelizmente, ideologicamente seus sucessores na historiografia teatral escrita a partir dos anos 60 e 70 do século XX no Brasil, com objetivos semelhantes, tratando que fossem desaparecidas. O que nos faz pensar e ler com extrema atenção as colocações pertinentes da pesquisadora Neyde Veneziano, quando diz que:

Se o Teatro de Revista contribuiu para a descolonização cultural do teatro brasileiro, se através dele fixamos nosso tipo, nosso cenário, nossos costumes, se através de sua linguagem cotidiana e despojada instalouse um preciso relato do falar a brasileira, se pelas suas críticas obtém-se um preciso relato do país, se os números atestam ter sido esta a forma teatral mais expressiva brasileira, deve-se questionar o desprezo absurdo e o preconceito obsessivo de que tem sido vítima (Veneziano, 1991, p.185).

As sequelas por todo um conjunto de ações voltadas para o objetivo de “apagamento" desse gênero teatral popular desdobraram-se em práticas narrativas depreciativas, desrespeitosas e, em muitos casos racistas, sem jamais levar em conta a participação e importância preponderante da cultura afrodescendente durante esse período e em todo um processo de formação identitária brasileira. Artifício que, por conseguinte, desprestigiou, sobremaneira, múltiplos grupos negros e mestiços viventes na cidade do Rio de Janeiro e de 
menor poderio econômico, sobretudo, aqueles residentes nos cortiços e favelas. Além do que, é sintomático constatar a inexistência da valorização, respaldo e/ou proteção da presença e importância da cultura negra nas políticas de Estado, leis, decretos, materiais didáticos, históricos e de divulgação pública, como jornais ou revistas da época.

Todo esse conjunto de ideias e vontades de inúmeros intelectuais deflagrou um projeto de orientação para a escrita de uma História presente que se adequasse a ambições de legitimação estética e ideológica, agora, de um teatro de perfil branco e europeu. Em um Estado com políticas prioritariamente eugênicas, ao contrário, o teatro cômico e musicado deveria ser duramente criticado e ter sua desimportância assumida publicamente, bem como ser considerado impróprio para servir de modelo aos anseios modernizantes que a Capital Federal precisaria oferecer à nação.

Enfrentamentos e ideias seriam localizadas em certas práticas do teatro cômico e musicado, que encapsulava em si peculiaridades de sua própria existência no seio de uma cultura citadina e, evidentemente, na capacidade de provocar uma elite eurodescendente, ao trazer para os palcos tradições execradas por ela.

Debilidade do projeto afrancesado das elites seria minada por um movimento subterrâneo e potente de abertura para valores miscigenados de cultura. Não é o caso de celebrá-los como valores de "resistência" das classes dominadas, ou de alternativamente acusar a apropriação indevida de elementos "autênticos" pelo poder. O fato é que só essa produção dialogizada de elementos interétnicos e interclasses foi capaz de lançar um projeto de identidade possível de ser aceito por amplos setores da população como sendo "a nossa cara" (Lopes, 2000, p.28).

Acontecimento artístico que prosseguia como uma espécie de entrecorte à polarização em relação a uma frente intelectual diametralmente oposta, defensora de um teatro literário, tendo o texto como centro. Uma calorosa defesa sobre a ideia de que o teatro (especialmente o texto) deveria se basear em pilares do melhor que a literatura ocidental havia produzido nas últimas décadas, em especial no realismo. Nitidamente, esse direcionamento de fisionomia textocentrista e conservadora, guardiã dos mais elevados valores moralizantes e 
pedagógicos que a arte literária poderia oferecer a uma sociedade, acabava por desvelar uma visão distorcida sobre as manifestações populares negras e mestiças que ocorriam na cidade.

\section{As reformas urbanas promovidas por Pereira Passos, a cidade dividida: "O Rio civiliza-se!"12}

O fato que se evidenciava, como já dito anteriormente, é que a cidade, nos primeiros anos do século XX, aspirava pela perspectiva de ser-europeu. Todo esse conjunto de vontades se apoiava em diversos e revigorados modelos para os modos e costumes do cidadão nos anseios da produção cultural e nas reformas urbanas capazes de emprestar um aspecto moderno à cidade.

Os técnicos do Governo Rodrigues Alves muito se esforçaram para implantar o plano cuja estratégia era projetar a Cidade no mercado internacional, através de obras inspiradas no modelo francês. Pereira Passos, prefeito do Distrito Federal entre janeiro de 1903 e novembro de 1906, almejava transformar a Cidade aos olhos do mundo e de alguns de seus cidadãos. Para tal, contou com os dispositivos da lei de 29 de dezembro de 1902, que, [...] conferiu ao prefeito poderes quase ditatoriais, que the permitiram inclusive despejar moradores de suas propriedades sem a anuência do Poder Judiciário. O programa de trabalho de Pereira Passos para modificar a imagem da Cidade, abrindo e alargando ruas, buscando retirar da paisagem do centro da Cidade os ambulantes e criando um cenário que atraísse os investidores estrangeiros [...] (Lima, 2000, p.97).

Assim, altera e corta-se a cidade criando avenidas, ruas e praças, bem ao gosto francês. Como síntese, uma fração da população pequeno-burguesa e faustosa ganharia o prazer de circular confortavelmente nas belas e recéminauguradas avenidas Central e Beira-Mar, finalizando seus passeios na Confeitaria Colombo, que, esplêndida, exprimiria charme e elegância, muito ao sabor dos seus clientes, em encontros matutinos e vespertinos. Entretanto, não podemos aqui deixar de registrar que a reurbanização significou a exclusão, pelo banimento, das populações de menor poderio econômico, sobretudo a negra, para áreas

${ }^{12}$ Expressão cunhada pelo jornalista fluminense Alberto Figueiredo Pimentel (1869-1914). Esta era o subtítulo da coluna "Binóculo", que assinava no jornal carioca Gazeta de Notícias: "O Rio civiliza-se". Convertida em exclamação, a frase andava em todas as bocas ao tempo das reformas da cidade realizadas por Pereira Passos. 
periféricas e mais distantes do centro da cidade. Excluídos, basicamente, por serem considerados elementos perigosos à ordem pública e estarem em desalinho com as novas diretrizes sanitárias impostas pelas oligarquias republicanas.

Espremidos entre uma elite governamental partidária de um intervencionismo arbitrário e uma elite burguesa que não desejava tê-los a seu lado como verdadeiros cidadãos, os pobres, por meio de motim, da desobediência às leis, do proselitismo de seus valores, revelavam à sociedade o seu inconformismo diante da tentativa de excluí-los do novo Rio que se estava construindo. Às reformas elitistas, respondiam com o seu avesso, habitando um espaço que não lhes tinha sido destinado, exercendo ofícios expressamente proibidos, praticando cultos que se queria desonrosos, permitindo-se a expansões de alegria que se tinha como indesejáveis (Pechman; Fritsch, 1984-85 apud Silva, 2019, p.416).

Exatamente nesta região, esquecida pela la fine fleur de la culture, grupos constituídos de negros e mestiços articulavam um conjunto de práticas culturais capazes de definirem uma identidade ligada a raízes africanas, na região denominada então de "Pequena África", dos lundus, jongos, maxixes e, posteriormente, do samba. Este último, fator crucial na construção da cultura carioca, se incorporaria aos festejos ao lado de práticas religiosas, batuques, danças, culinária, com a finalidade de resguardar uma tradição afro-brasileira. Esse conjunto de práticas desponta para a afirmativa demarcação da presença da cultura negra, que perseverava no confronto ao status quo branco, presente e influente nas políticas de Estado.

Na cidade do Rio de Janeiro, nas primeiras décadas do século XX, restavam ainda memórias ingratas, relembradas a todo momento pela presença de uma população vasta de ex-escravizados e seus descendentes. O término do Império, o fim do sistema escravocrata e outros fatores históricos de ordem econômica e social ocasionaram uma tensão, entre causa e efeito, nas tentativas de consolidação identitária de uma população carioca, massificada e ainda aturdida por tantas mudanças posteriores à Abolição e à Proclamação da República. O fato é que naquele momento tudo se colocava em choque, dificultando qual noção de nacionalismo, modernidade e brasilidade poderia vigorar. 
O Rio de Janeiro desejava se mostrar para o mundo (leia-se aqui especialmente para a Europa) com uma aparência de prosperidade, desenvolvida para esse novo período da vida política e cultural. A belle époque carioca definia, ou pelo menos pretendia demarcar, um modo diferenciado de ser. O Brasil de um passado rural, imperial, escravocrata e subdesenvolvido deveria definitivamente ficar para trás, esquecido. Em substituição, novos anseios modernizantes, contemporâneos, liberais e industriais para uma Capital que desejava se espelhar e ser capaz de reproduzir nos trópicos o melhor do mundo civilizado. Nesse contexto interessava a distinção entre uma cultura de aspecto erudito (evidentemente idealizada), salutar, nacionalista, e outra, afrodescendente, baixa, até mesmo perniciosa, e perigosamente transeunte nas áreas públicas da cidade, sendo reveladora para o mundo da existência de uma nação negra e brasileira.

Em meio a essas áreas públicas estava a Praça Tiradentes, com seus teatros, dancings, cafés e restaurantes, onde se reunia à noite um público diversificado, trabalhadores de baixa e média renda, "homens" de letras, jornalistas e artistas de teatro, fazendo daquele o centro da boemia carioca e espaço de sociabilidade. Poderíamos ainda dizer, ou conjecturar, que esse espaço de arte, vida boêmia e socialização mostrou-se como um lugar de intersecções, onde o modelo branco, letrado e europeu estava presente, mas banhava-se ao Sol, bronzeando-se. Espaço teatral, onde com muito humor e ao som do maxixe e depois do samba, dar-se-ia lugar ao maneirismo crítico e brejeiro que determinaria o modo de ser do(a) carioca.

Desde a década de 20, mútuas influências ocorreram entre o samba e o teatro de revista carioca, devido à participação de músicos e compositores negros naqueles espetáculos. A estética do teatro de revista foi fortemente influenciada pelo estilo irreverente do samba e este, por sua vez, inicialmente criado em torno do jogo lúdico e do ritual animista, começou a se diversificar, incorporando monólogos e outras formas de narração típicas do teatro de revista. Desde então, o samba passou a expressar os conflitos do dia a dia e os dramas pessoais do povo e da classe média brasileira. Muitos foram os números teatrais que resultaram desta fórmula, tanto cômico quanto dramático. A associação entre os sambistas e os artistas do teatro de revista criou um campo fértil para o desenvolvimento das formas populares do fazer cultural carioca. E, partindo da capital, essa síntese cultural conquistou o Brasil (Ligiéro, 2011, p.162). 
A questão é que o teatro que acontecia na Praça Tiradentes reportaria para sua estrutura performática os festejos encontrados nas ruas, fosse pelo texto, expressão de gestos, batuques, cantos ou danças. Parecia, e seria, um caminho sem volta.

\section{Considerações finais}

Como conclusão, se de um lado o desejo de modernidade se colocava forçosamente nas transformações civilizatórias e urbanas patrocinadas pelas elites, de outro, a identidade do carioca desenhava-se nas noites boemias, nos bares e na criação do hábito de beber cerveja, nos jongos, capoeiras, batucadas e rodas de samba, que tornavam-se cada vez mais comuns pela cidade..$^{13} \mathrm{O}$ teatro cômico e musicado espelhava tudo isso. Dialogicamente, recriava e reinventava todo esse conjunto de coisas, sendo capaz de absorver, em sua essência, as nuances capazes de delinear um imaginário para a cidade do Rio de Janeiro e para a população carioca.

Por fim, os questionamentos que nos ficam são: qual o lugar das representações sociais para as populações negra e mestiça se suas tradições culturais eram recorrentemente depreciadas ou mesmo apagadas em uma linha do tempo-histórico por homens de "intelecto", brancos e de ascendência europeia? Como resguardar as múltiplas práticas culturais afrodescendentes sem que se tenha um contexto identitário e ancestral preservado? Portanto, distinguir todo um conjunto de ações visivelmente direcionadas ao menosprezo e posterior esquecimento de uma vasta e riquíssima cultura herdada de um sistema violento e escravocrata que perdurou em solo brasileiro por 388 anos, é, antes de tudo, um ato de reconhecimento aos ataques que se instauraram sobre tradições afrobrasileiras. Ao mesmo tempo, permite (re)apreciar as concretizações do teatro cômico e musicado e sua importância artístico-cultural. E, acima de tudo, dá sentido e visibilidade para uma história existente, rica, intricada e preenchida de

${ }^{13}$ Cabe aqui ressaltar que nem sempre essas práticas aconteciam sem que houvesse ações de proibição, repressão e, em muitos casos, de prisões - pelas forças policiais - de negros(as) e mestiços(as) de que delas participavam. 
experiências vividas e de luta.

\section{Referências}

ALBERTI, Verena. O riso e o risível: na história do pensamento. Rio de Janeiro: Jorge Zahar Ed/FGV, 1999.

CHARTIER, Roger. "Cultura popular": revisitando um conceito historiográfico. Estudos Históricos, Rio de Janeiro, vol. 8, n. 16, p.179-192, 1995.

CHARTIER, Roger. A história cultural: entre práticas e representações. Lisboa: Difel, 1990.

GUĖNOUN, Denis. A Exibição das Palavras: uma ideia (política) do teatro. Rio de Janeiro: Teatro do Pequeno Gesto: Folhetim Ensaios, 2003.

HALBWACHS, Maurice. A memória coletiva. São Paulo: Edições vértice, Editora Revista dos Tribunais Ltda., 1990.

LE GOFF, Jacques. Memória. In: Enciclopédia Einaudi, v.I. Memória-História. Lisboa: Imprensa Nacional-Casa da Moeda, 1984.

LIGIÉRO, Zeca. Cantar-Dançar-Batucar. In: Corpo a corpo: estudo das performances brasileiras. Rio de Janeiro: Garamond, 2011.

LIMA, Evelyn Furquim Werneck. Arquitetura do Espetáculo: teatros e cinemas na formação da Praça Tiradentes e da Cinelândia. Rio de Janeiro: Ed. UFRJ, 2000.

LOPES, Antônio H. O Teatro de Revista e a Identidade Carioca. In: LOPES, Antônio Herculano (org.). Entre Europa e África: a invenção do carioca. Rio de Janeiro: Fundação Casa de Rui Barbosa; Topbooks, 2000.

PEREIRA, Amilcar. Por uma autêntica democracia racial!: os movimentos negros nas escolas e nos currículos de história. Revista História Hoje, [s. l.], v. 1, n. 1, p. 111128, 2012.

POLLAK, Michael. Memória e identidade social. Estudos Históricos, Rio de Janeiro, vol. 5, n. 10, p. 200-212, 1992.

SCHWARCZ, Lilia Moritz. O Espetáculo das Raças - cientistas, instituições e questão racial no Brasil 1870-1930. São Paulo: Companhia das Letras, 1993. 
SILVA, Mayara Grazielle Consentino Ferreira da. Reforma Urbana Pereira Passos: resistências de uma população excluída. Revista de Ciências Sociais, Fortaleza, v. 50, n. 1, mar./jun., p. 409-447, 2019.

VENEZIANO, Neyde. O teatro de revista no Brasil: dramaturgia e convenções. Campinas, SP: Editora da Universidade Estadual de Campinas, 1991.

Recebido em: 14/06/2021

Aprovado em: 12/08/2021 